\title{
Seasonal occurrence of metazoan parasites in Tigerfish, Hydrocynus vittatus Castelnau, 1861 (Characiformes: Alestidae) from Sanyati Basin, Lake Kariba, Zimbabwe
}

\begin{tabular}{|c|c|}
\hline \multicolumn{2}{|c|}{ 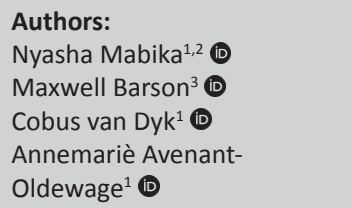 } \\
\hline \multicolumn{2}{|c|}{$\begin{array}{l}\text { Affiliations: } \\
\text { 'Department of Zoology, } \\
\text { University of Johannesburg, } \\
\text { Johannesburg, South Africa }\end{array}$} \\
\hline \multicolumn{2}{|c|}{$\begin{array}{l}\text { 'Department of Anatomy, } \\
\text { University of Zimbabwe, } \\
\text { Harare, Zimbabwe }\end{array}$} \\
\hline \multicolumn{2}{|c|}{$\begin{array}{l}{ }^{3} \text { Department of Biological } \\
\text { Sciences, University of } \\
\text { Zimbabwe, Harare, Zimbabwe }\end{array}$} \\
\hline \multicolumn{2}{|c|}{$\begin{array}{l}\text { Corresponding author: } \\
\text { Annemariè Avenant- } \\
\text { Oldewage, } \\
\text { aoldewage@uj.ac.za }\end{array}$} \\
\hline \multicolumn{2}{|c|}{$\begin{array}{l}\text { Dates: } \\
\text { Received: } 18 \text { June } 2018 \\
\text { Accepted: } 15 \text { Feb. } 2019 \\
\text { Published: } 22 \text { Aug. } 2019\end{array}$} \\
\hline \multicolumn{2}{|c|}{$\begin{array}{l}\text { How to cite this article: } \\
\text { Mabika, N., Barson, M., } \\
\text { Van Dyk, C. \& Avenant- } \\
\text { Oldewage, A., 2019, } \\
\text { 'Seasonal occurrence } \\
\text { of metazoan parasites } \\
\text { in Tigerfish, Hydrocynus } \\
\text { vittatus Castelnau, } 1861 \\
\text { (Characiformes: Alestidae) } \\
\text { from Sanyati Basin, Lake } \\
\text { Kariba, Zimbabwe', } \\
\text { Onderstepoort Journal of } \\
\text { Veterinary Research } 86(1) \text {, } \\
\text { a1659. https://doi.org/ } \\
\text { 10.4102/ojvr.v86i1.1659 }\end{array}$} \\
\hline \multicolumn{2}{|l|}{ Read online: } \\
\hline 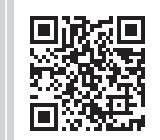 & $\begin{array}{l}\text { Scan this QR } \\
\text { code with your } \\
\text { smart phone or } \\
\text { mobile device } \\
\text { to read online. }\end{array}$ \\
\hline
\end{tabular}

\section{Authors:}

Maxwell Barson 3

Cobus van Dyk ${ }^{1}$ (1)

Annemariè Avenant-

Oldewage $^{1} \mathbb{0}$

Affiliations:

${ }^{2}$ Department of Anatomy, University of Zimbabwe,

Sciences, University of

Corresponding author:

Annemariè Avenant-

Oldewage

Dates:

Received: 18 June 2018

Accepted: 15 Feb. 2019

How to cite this article: Mabika, N., Barson, M., Van Dyk, C. \& Avenantin Tigerfish, Hydrocynus vittatus Castelnau, 186 (Characiformes: Alestidae) from Sanyati Basin, Lak Veterinary Research 86(1) a1659. https://doi.org/ 10.4102/ojvr.v86i1.1659

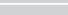

\begin{abstract}
Lake Kariba is a tropical lake with slight variations in seasonal temperature. Temperature is an important physical variable in the biology of both fish and their parasites. Currently, there is no information on the seasonal occurrence of fish parasites in Lake Kariba. The objective of this study was to investigate the seasonal occurrence of metazoan parasites in Hydrocynus vittatus in Lake Kariba, Zimbabwe. Twenty fish specimens were collected by seine netting per season between October 2014 and July 2015 in the Sanyati Basin, Lake Kariba, and examined for metazoan parasites. Mean water temperatures ranged from $24.1{ }^{\circ} \mathrm{C}$ to $31.2{ }^{\circ} \mathrm{C}$ with slight variations between the seasons. Metazoan parasites consisting of Monogenea (Annulotrema pikei, Annulotrema pseudonili, Annulotrema bracteatum), Nematoda (Contracaecum larvae), Copepoda (Lamproglena hemprichii), Cestoda (larval cestodes, Ichthybothrium sp.) and Pentastomida (pentastomid larvae) were recorded. Larval cestodes were recorded in autumn and spring, while pentastome larvae were recorded in summer and spring. The Ichthybothrium sp. was recorded once in winter. Annulotrema pikei and A. pseudonili were observed on the gills and $A$. bracteatum on both the gills and the skin. Contracaecum larvae, L. hemprichii and A. bracteatum (from the skin) were recorded in all the seasons, with slight variations in prevalence, mean abundance and mean intensity. However, these variations were not statistically significant (analysis of variance or ANOVA, $p>0.05$ ). The slight variations in occurrence of the parasites were probably because of the thermal stability of the lake where variation in temperature was small between seasons. Both A. bracteatum and Contracaecum larvae were aggregated on the fish host, whereas L. hemprichii exhibited a random distribution. Parasite diversity was at its highest during winter.
\end{abstract}

Keywords: Annulotrema; Contracaecum; cestode; Lamproglena; prevalence; aggregation.

\section{Introduction}

Fish are hosts to many protozoan, helminth and arthropod parasites (Branson \& Southgate 1992). These parasites are generally in equilibrium with their hosts (Marcogliese 2005). However, there are times when changes in the environment can change the state of balance of the parasite between host and nature, thus resulting in disease (Lafferty \& Kuris 1999). According to Eissa (2002), about $80 \%$ of fish diseases are because of parasite infections, especially in warm water fish; therefore, parasitic diseases remain important problems confronting modern fisheries (Ravichandran, Balasubramanin \& Kannupandi 2007). Fish may also serve as paratenic or intermediate or definitive hosts of parasites, and some of these parasites can even be transferred to humans (Adams, Murrell \& Cross 1997).

Some fish parasites are encountered during all seasons, some during certain seasons, or large differences occur in their seasonal abundance and prevalence. This is mainly because of physical and chemical changes in water quality, geographical isolation, inhabitancy and nourishment, or the presence and density of intermediate hosts (Möller \& Anders 1986). Temperature is another important environmental variable affecting the seasonal occurrence of parasites because it affects both the host and the parasite (Xenopoulos, Lodge \& Alcamow 2005).

Tigerfish, Hydrocynus vittatus Castlenau, 1861, are widely distributed in sub-Saharan Africa. In Southern Africa, it is the only representative of the genus Hydrocynus (Skelton 2001).

Copyright: (C) 2019. The Authors. Licensee: AOSIS. This work is licensed under the Creative Commons Attribution License. 
Parasites of $H$. vittatus have been recorded in countries such as Botswana, Zimbabwe and South Africa. Most of these studies primarily focussed on single parasite groups in H. vittatus such as nematodes (Boomker 1994; McHugh et al. 2011), copepods (Douëllou \& Erlwanger 1994), monogeneans (Christison, Van As \& Basson 1998; Kunutu et al. 2018; Price, Peebles \& Bamford 1969) and myxozoans (Reed, Basson \& Van As 2002). To date, six Annulotrema (Monogenea) species have been recorded in the African tigerfish. Paperna (1973) described Annulotrema magna and Annulotrema ruahae in Tanzania. Annulotrema niliruahae and Annulotrema pikei ruahae were also described in Tanzania by Paperna (1979). Annulotrema pikei was recorded in Uganda, Ghana and South Africa by Price et al. (1969) and A. pikoides was described in Mali (Guégan, Lambert \& Birgi 1988).

Metazoan parasites consist of a big group infecting almost every organ of the fish host and may cause pathological, physiological, morphological and biochemical changes in infected tissues. Most parasites are pathogenic and weaken the host fish, thereby inducing stress in the host fish (Pardeshi, Hiware \& Wangswad 2012). Parasites also affect host survival, reproduction, alter fish behaviour and migration patterns, and can even regulate fish populations and affect community structure (Garnick \& Margolis 1990).

Previous studies on the parasites of H. vittatus in Lake Kariba have focussed on their diversity and taxonomy (Douëllou 1992; Douëllou \& Erlwanger 1993; Mabika et al. 2016). These studies excluded information on the parasite community of $H$. vittatus related to spatial-temporal changes in the lake. For example, variation in the temperature has been suggested to influence the seasonal variation of parasite communities in fish (Felis \& Esch 2004; Šimková et al. 2005). Studies on the seasonal occurrence of parasites may indicate periods during which epizootic outbreaks are likely to be favoured, and such knowledge is important to prevent economic losses for fisheries (Tavares-Dias et al. 2014). For this reason, the objective of the study was to investigate whether the season plays a role in metazoan parasite infections in $H$. vittatus, in the Sanyati Basin, Lake Kariba, Zimbabwe.

\section{Materials and methods \\ Sampling of fish and examination of parasites}

Sampling was carried out seasonally from October 2014 to July 2015 on the Zimbabwean side of the Sanyati Basin. Twenty fish specimens were collected during each of the four seasons using seine netting along a $15-\mathrm{km}$ stretch of the northern shoreline near Kariba town (Figure 1), and also during the Kariba Invitation Tiger Fishing Tournament held at the Charara Bay in October 2014. The fish were transported live in lake water to the laboratory. In the study, the following were recorded or calculated: (1) water physico-chemical parameters, (2) infection parameters, (3) the effect of parasites on the condition factor (CF) of the host, (4) the relationship between host size and infection and (5) aggregation.

\section{Water quality parameters}

Selected surface water quality parameters were recorded in situ on a seasonal basis from October 2014 to July 2015 in the Sanyati Basin, Lake Kariba. These parameters included temperature, dissolved oxygen (DO), $\mathrm{pH}$ and electrical conductivity. Surface water temperature and DO were measured using a $\mathrm{HACH} 330 \mathrm{i}$ oxygen probe, while $\mathrm{pH}$ and conductivity were measured using a $\mathrm{HACH} \mathrm{pH}$ meter and WTW 330i conductivity meter.

Standard and total lengths $(\mathrm{cm})$, weight $(\mathrm{g})$ and sex (after dissection) of the fish were recorded. Parasites were collected from the fins, skin, gills, liver, body cavity, mesentery, stomach, intestines, kidney, brain cavity, swim bladder, muscle and eyes. Observed parasites were identified using the keys of Barson and Avenant-Oldewage (2006), Douëllou and Erlwanger (1994), Luus-Powell, Jooste and Junker (2008), Kuchta et al. (2012) and Kičinjaová et al. (2017). Monogeneans, Lamproglena sp. Contracaecum larvae and adult cestodes were also subjected to molecular analysis. Pentastome larvae could not be subjected to molecular analysis because of its poor fixation. Procedures for treatment, fixation, preservation and examination of parasites followed those of MadanireMoyo and Barson (2010).

\section{Data analysis}

The prevalence, mean abundance and mean intensity of the parasites were calculated as defined by Bush et al. (1997). The effect of the parasites on the condition of their host was determined by calculating the CF following the method of Pauly (1983):

$\mathrm{CF}=\mathrm{W} \times 100 / \mathrm{L}^{3}$

[Eqn 1]

where

CF is the condition factor

$\mathrm{W}$ is the total weight of the fish $(\mathrm{g})$

$\mathrm{L}$ is the standard length of the fish $(\mathrm{cm})$.

Data were analysed using the Statistical Analysis System Version 9.3(SAS20022010). Normality and homoscedasticity were tested using the UNIVARIATE PLOT and Levene's test procedures, respectively. The effect of the season on the mean abundance of specific parasite species was determined using the PROC GLM procedure of SAS in which the season was fitted as the only fixed variable in the model. Tukey's method was used to compare the means. Regression analyses were performed to determine if fish size and fish CF were associated with the number of individual parasite species. 


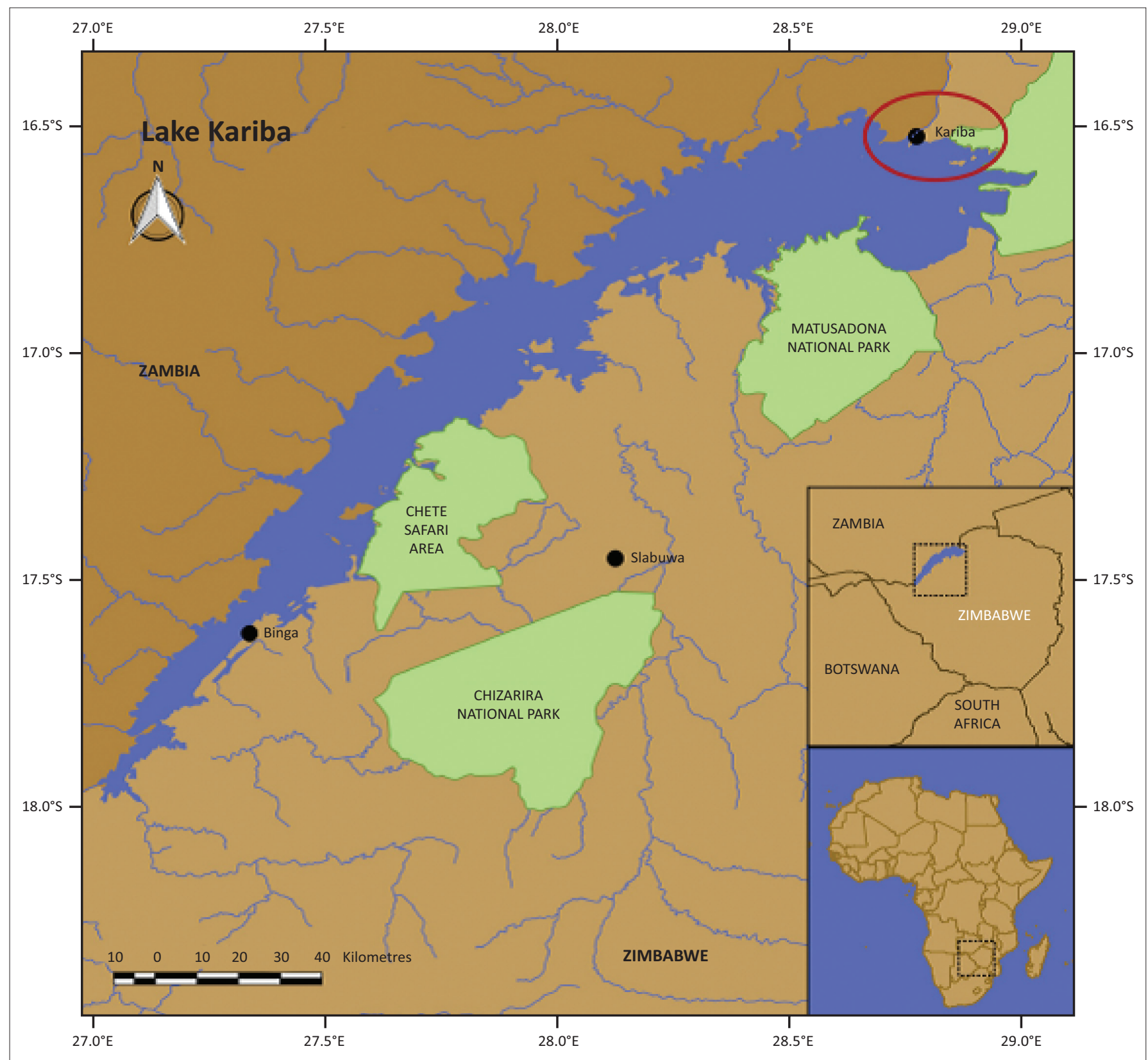

FIGURE 1: A map of Lake Kariba showing the location of the Sanyati Basin.

The magnitude of aggregation was determined following the method of Elliott (1977) by calculating the variance/mean ratio. The ratios were interpreted as follows:

- Variance and mean are approximately the same: Parasites are randomly distributed.

- Variance/mean ratio increases above 1: Parasites are aggregated.

- Variance/mean ratio is less than 1: Parasites are uniformly distributed.

\section{Ethical considerations}

Ethical approval was granted by the University of Johannesburg Ethical Committee, Protocol January 2015 and acquisition of an appropriate research permit issued by the Zimbabwe Parks and Wildlife Management Authority (permit number 23(1)(C)(11)09/2014).

\section{Results}

\section{Water quality parameters}

Mean seasonal water temperatures ranged from $24.1{ }^{\circ} \mathrm{C}$ in winter to $31.2{ }^{\circ} \mathrm{C}$ in spring (Table 1). An alkaline $\mathrm{pH}$ was recorded in all seasons with winter having the highest $(8.2 \pm 0.19)$ and autumn the lowest $\mathrm{pH}(7.4 \pm 0.63)$. Mean DO was the lowest in autumn $(4.7 \pm 3.9 \mathrm{mg} / \mathrm{L})$ and the highest in winter $(8.5 \pm 0.10 \mathrm{mg} / \mathrm{L})$. The lowest mean conductivity $(91.1 \pm 15.9 \mu \mathrm{S} / \mathrm{cm})$ was recorded in winter. The highest mean conductivity $(157 \pm 100.54 \mu \mathrm{S} / \mathrm{cm})$ was recorded in summer.

\section{Parasites}

A total of 80 fish specimens were examined for parasites. All fish specimens were infected with at least one parasite species. Five metazoan taxa comprising monogeneans 
(Annulotrema pseudonili, A. pikei, Annulotrema bracteatum), nematodes (Contracaecum larvae), copepods (Lamproglena hemprichii), cestodes (larval cestodes, Ichthybothrium sp.) and pentastome larvae were recorded (Table 2). Larval cestodes were recorded in autumn and spring, while pentastome larvae were recorded in summer and spring. Ichthybothrium sp. was recorded once in winter. Annulotrema pseudonili, A. pikei and L. hemprichii were recorded from the gills, while $A$. bracteatum was recorded from both the gills and the skin. Annulotrema pseudonili, A. pikei and $A$. bracteatum could not be separated from the fish gills because they were identified from the gills by molecular analysis. The $28 \mathrm{~S}$ and $18 \mathrm{~S}$ rDNA (ribosomal DNA) fragments of L. hemprichii were distinct from other Lamproglena taxa. DNA analysis of Contracaecum larvae showed that it was closely related to the marine nematode Contracaecum osculatum, with a $10 \%$ difference in DNA. The DNA sequence data of the Annulotrema spp. and cestode were not included in this article as they will be provided in future papers focussing on taxonomy and morphology.

Therefore, separating all the Annulotrema species would entail molecular analysis of each individual parasite and considering the abundance of these parasites, this could possibly be suggested to be performed in future studies. Consequently, their seasonal prevalence, mean intensity and mean abundance from the gills were not determined. Contracaecum larvae and larval cestodes were recorded from the body cavity and mesentery. The Ichthybothrium specimens were observed from the small intestine, while the pentastome larvae were recorded from the brain cavity and swim bladder.

\section{Seasonal prevalence of the parasites}

Annulotrema bracteatum, Contracaecum larvae and L. hemprichii occurred throughout all seasons (Table 2). The prevalence of A. bracteatum was the same $(30 \%)$ in summer and autumn. It reached a peak in winter and declined slightly in spring. Contracaecum larvae also showed slight variations in prevalence which reached a peak in winter and declined

TABLE 1: Value of selected physicochemical water quality parameters (mean \pm standard deviation) during four seasons (October 2014-July 2015) in the Sanyat Basin, Lake Kariba.

\begin{tabular}{lcccc}
\hline Season & $\mathrm{T}\left({ }^{\circ} \mathrm{C}\right)$ & $\mathrm{pH}$ & $\begin{array}{c}\text { Dissolved } \\
\text { oxygen }(\mathrm{mg} / \mathrm{L})\end{array}$ & $\begin{array}{c}\text { Conductivity } \\
(\mu \mathrm{S} / \mathrm{cm})\end{array}$ \\
\hline Spring (October 2014) & $31.2 \pm 0.75$ & 7.5 & $8.01 \pm 0.56$ & $137.5 \pm 50.2$ \\
Summer (January 2015) & $29.6 \pm 0.51$ & 7.8 & $5.46 \pm 4.52$ & $157 \pm 100.54$ \\
Autumn (April 2015) & $30.2 \pm 0.60$ & 7.4 & $4.7 \pm 3.9$ & $121.6 \pm 27.68$ \\
Winter (July 2015) & $24.1 \pm 0.44$ & 8.2 & $8.5 \pm 0.10$ & $91.1 \pm 15.9$ \\
\hline
\end{tabular}

in spring. There was also a slight variation in the prevalence of L. hemprichii which increased from summer to winter and peaked in winter before it declined in spring. The prevalences of larval cestodes were $30 \%$ and $5 \%$ in autumn and spring, respectively. Pentastome larvae had the same prevalence $(5 \%)$ in both summer and spring. The Ichthybothrium sp. had a prevalence of $5 \%$ in winter.

\section{Seasonal mean intensity of the parasites}

Table 2 shows that there was a slight variation in the mean intensities of parasites throughout the seasons. Contracaecum larvae decreased between summer and autumn, followed by an increase in winter. Mean intensity peaked in spring, when water temperature was at a maximum. The mean intensity for $A$. bracteatum decreased from summer to autumn and reached a peak in winter when water temperature was at its lowest. The numbers declined in spring. The maximum mean intensity for L. hemprichii was recorded in summer. It declined in autumn and then gradually increased from winter to spring.

\section{Seasonal mean abundance of the parasites}

Small seasonal variations in mean abundance were observed for the parasites (Table 3). Parasite numbers were lowest in autumn when $\mathrm{DO}$ and $\mathrm{pH}$ levels were also at their minimum; A. bracteatum, Contracaecum larvae and L. hemprichii decreased from summer to autumn, peaked in winter and declined in spring. Larval cestodes had a higher mean abundance in autumn than in spring. The mean abundance of pentastome larvae was the same in both summer and spring.

Results from the PROC GLM showed no statistically significant differences $(p>0.05)$ in the mean abundances of A. bracteatum, L. hemprichii and Contracaecum larvae throughout the seasons. Unfortunately, the sample sizes for the other parasites (larval cestodes, pentastome larvae and Ichthybothrium sp.) were too small to enable statistical analysis.

TABLE 3: Mean abundance of metazoan parasites infecting Hydrocynus vittatus $(n=20)$ per season.

\begin{tabular}{lcccc}
\hline Parasite & Summer & Autumn & Winter & Spring \\
\hline Annulotrema bracteatum & 7.05 & 5.28 & 8.2 & 6.24 \\
Contracaecum larvae & 0.41 & 0.38 & 0.55 & 0.49 \\
Lamproglena hemprichii & 0.19 & 0.15 & 0.25 & 0.23 \\
Larval cestode & 0.00 & 0.53 & 0.00 & 0.03 \\
Ichthyobothrium sp. & 0.00 & 0.00 & 0.30 & 0.00 \\
Pentastomid & 0.01 & 0.00 & 0.00 & 0.01 \\
\hline
\end{tabular}

TABLE 2: Prevalence and mean intensity per season of metazoan parasites of Hydrocynus vittatus $(n=20)$ per season.

\begin{tabular}{|c|c|c|c|c|c|c|c|c|}
\hline \multirow[t]{2}{*}{ Parasite } & \multicolumn{4}{|c|}{ Prevalence $\%$} & \multicolumn{4}{|c|}{ Mean intensity } \\
\hline & Summer & Autumn & Winter & Spring & Summer & Autumn & Winter & Spring \\
\hline Annulotrema bracteatum & 30 & 30 & 45 & 40 & 24.3 & 19 & 27.11 & 22.4 \\
\hline Contracaecum larvae & 25 & 20 & 35 & 25 & 5.25 & 4.9 & 6.3 & 7.8 \\
\hline Lamproglena hemprichii & 20 & 25 & 40 & 35 & 2 & 1.6 & 1.7 & 1.9 \\
\hline Larval cestode & 0 & 30 & 0 & 5 & 0 & 7 & 0 & 2 \\
\hline Pentastomid & 5 & 0 & 0 & 5 & 1 & 0 & 0 & 1 \\
\hline Ichthybothrium sp. & 0 & 0 & 5 & 0 & 0 & 0 & 6 & 0 \\
\hline
\end{tabular}




\section{Body length in relation to parasitic infection}

The total number of parasites and mean intensity of infection were recorded for four different body size classes of $H$. vittatus (Table 4). The number of fish examined in each group varied and the number of parasites recovered in each respective body size group also varied. Most fish were in the $20.1 \mathrm{~cm}-29.0 \mathrm{~cm}$ and $29.1 \mathrm{~cm}-38.0 \mathrm{~cm}$ size classes and most parasites were recorded in the $20.1 \mathrm{~cm}-29.0 \mathrm{~cm}$ group. Regression analysis showed that there was no relationship between fish size and number of parasites $(p>0.05)$.

\section{Seasonal mean condition factor of parasitised Hydrocynus vittatus}

Seasonal variations in CFs were observed. The highest mean CFs were recorded in summer and the lowest mean CFs were observed in winter for both the male and female fish (Table 5). However, the seasonal variations in CFs were not statistically significant $(p>0.05)$. The regression analysis showed that there was no relationship between parasite abundance and CF $(p>0.05)$.

\section{Aggregation of parasites}

The data for all surveys were pooled to determine whether aggregation occurred. The variance/mean ratios of A. bracteatum and Contracaecum larvae were all greater than 1 (Table 6), indicating an aggregated distribution. However, A. bracteatum was more aggregated than the Contracaecum larvae. The variance and the mean of L. hemprichii were approximately the same, indicating a random distribution of the parasites on the host.

\section{Discussion}

This study for the first time investigated various aspects of the ecology of metazoan parasites in H. vittatus from Lake Kariba. Five metazoan parasite taxa consisting of three monogeneans,

TABLE 4: Total number of parasites and mean intensity in each size class of Hydrocynus vittatus.

\begin{tabular}{lccc}
\hline Size class $(\mathbf{c m})$ & $\boldsymbol{N}$ & Total no. of parasites & Mean intensity \\
\hline $11-20$ & 5 & 1178 & 235.6 \\
$20.1-29$ & 44 & 6541 & 148.7 \\
$29.1-38$ & 26 & 5387 & 207.2 \\
$38.1-47$ & 5 & 972 & 194.4 \\
\hline
\end{tabular}

$N$, number.

TABLE 5: Mean condition factor per season of parasitised female and male Hydrocynus vittatus per season in the Sanyati Basin, Lake Kariba.

\begin{tabular}{lcc}
\hline Season & Female & Male \\
\hline Summer & $1.74 \pm 0.15$ & $1.65 \pm 0.25$ \\
Autumn & $1.60 \pm 0.19$ & $1.61 \pm 0.14$ \\
Winter & $1.57 \pm 0.17$ & $1.48 \pm 0.33$ \\
Spring & $1.58 \pm 0.19$ & $1.55 \pm 0.12$ \\
\hline
\end{tabular}

TABLE 6: Levels of aggregation of parasites on Hydrocynus vittatus.

\begin{tabular}{lcccc}
\hline Parasite & $\begin{array}{c}\text { No. of fish } \\
\text { hosts }\end{array}$ & Variance & $\begin{array}{c}\text { Mean } \\
\text { intensity }\end{array}$ & $\begin{array}{c}\text { Variance/ } \\
\text { mean ratio }\end{array}$ \\
\hline Annulotrema bracteatum & 33 & 2242 & 29.03 & 77.2 \\
Lamproglena hemprichii & 31 & 1.77 & 2 & 0.89 \\
Contracaecum larvae & 22 & 34.6 & 4.18 & 8.3 \\
\hline
\end{tabular}

one copepod, two cestodes, larval nematodes and larval pentastomes were recorded. The parasite community of $H$. vittatus was dominated by A. bracteatum in all the seasons, while parasites such as larval cestodes, Ichthybothrium sp. and pentastome larvae were occasionally observed. The majority of the host fish were in the $20.1 \mathrm{~cm}-29.0 \mathrm{~cm}$ and $29.1 \mathrm{~cm}-$ $38.0 \mathrm{~cm}$ size classes and this size class also carried the highest parasite burden. A regression analysis showed that there was no relationship between fish size and parasite infrapopulation $(p>0.05)$.

An alkaline $\mathrm{pH}$ was recorded for all the seasons, with the minimum recorded in autumn and the maximum in winter. Maximum $\mathrm{pH}$ is normally expected in autumn just after the rainy season (Buckle 1996). However, the maximum $\mathrm{pH}$ recorded in winter was probably because of the rains which fell late in summer and autumn. The maximum difference between the cold and warm season was $8^{\circ} \mathrm{C}$, confirming the statement by Bashirullah and Hafizuddin (2007) that temperature in the tropics varies little between seasons. Under such situations, seasonal changes in the behaviour of parasites are not expected (Bashirullah \& Hafizuddin 2007). This was confirmed in the present study as there were slight variations in the occurrence of the parasites throughout the seasons. However, in temperate regions, the population dynamics of parasites such as the monogeneans is influenced by water temperature, which directly affects the parasite's reproduction and survival (Mo 1997) as well as their existence and abundance (Koskivaara, Valtonen \& Prost 1991) and determines the immune response of the host (Aaltonen, Jokinen \& Valtonen 1994). While some monogeneans tend to reproduce more rapidly at a higher water temperature, others prefer cooler water temperatures (Hanzelova \& Zitňan 1985). In the present study, A. bracteatum had the highest mean abundance in winter suggesting a preference for cooler temperatures. Minimum DO levels were recorded in autumn, while maximum levels were recorded in winter. Low levels of DO in autumn could probably be because of a reduced photosynthetic activity of aquatic plants and algae. Peak DO levels in winter could be attributed to low temperatures, increased plant and algal photosynthetic activity and strong turbulences because of the late rains in summer and autumn. Conductivity was minimum in winter, while maximum conductivity in summer could be because of a combination of anthropogenic activities and an increase in temperature. Annulotrema bracteatum, Contracaecum larvae and L. hemprichii, recorded throughout the seasons, had their maximum prevalence in winter when DO was maximum. This could possibly suggest that these parasites thrive in winter when DO is at its maximum. The other parasites (larval cestodes, pentastome larvae and Ichthyobothrium sp.) were not recorded throughout the seasons; hence, it was not possible to establish their prevalence in relation to DO levels.

Contracaecum sp. is not host-specific in the larval stage (Al-Zubaidy 2009) and the larvae usually occur in the body cavity of the fish (Whitfield \& Heeg 1977). They showed a variation in prevalence and reached a peak in winter, but 
this was not statistically significant. According to Huizinga (1967), Contracaecum eggs hatch in water with an optimum temperature of $21^{\circ} \mathrm{C}$.

Though seasonal variation in the prevalence of L. hemprichii was observed, the variation was not statistically significant. Of note was that peak prevalence was recorded in winter, while Austin and Avenant-Oldewage (2009) recorded the maximum infection of $L$. hoi on Labeo barbus polylepis in Mpumalanga (temperate region) in spring and lowest in winter. This is also contrary to observations by Tsotetsi, Avenant-Oldewage and Mashego (2004) who recorded the maximum prevalence of L. clariae in Clarias gariepinus in the Vaal Dam (temperate region) during autumn and winter, with a decrease in spring and early summer.

Larval cestodes and pentastome larvae were recorded twice, while the Ichthybothrium sp. was recorded once. This may be attributed to ecological conditions and particularly the distribution or absence of intermediate hosts (Puinyabati et al. 2010). Single pentastome larvae were recorded in female hosts during summer and spring. According to Junker, Boomker and Booyse (1998), pentastome infections are rare in fish. Fish species that are bottom feeders are readily exposed to pentastomes while feeding on detritus or water plants (Junker et al. 1998). Top feeders such as H. vittatus are therefore not exposed to pentastome larvae and this could probably explain why they were rarely observed in the H. vittatus.

Fish of the genus Hydrocynus seem to be paratenic, accidental or post-cyclic hosts of both riocephalidean cestodes (Kuchta et al. 2012). This was also confirmed in this study as Ichthybothrium sp. was recorded only once and could possibly indicate that $H$. vittatus is an accidental or rare host.

The reproduction season for $H$. vittatus in Lake Kariba is in summer (Kenmuir 1973). According to Buchmann and Uldal (1997), it is assumed that fish are more susceptible to parasite infection during periods of reproduction. However, this is contrary to the results of the current study as parasite populations peaked in winter when the temperature was at its minimum and $\mathrm{DO}$ and $\mathrm{pH}$ were at the maximum. Minimum prevalence and mean abundance for A. bracteatum, Contracaecum larvae and L. hemprichii were recorded in autumn when $\mathrm{DO}$ and $\mathrm{pH}$ were at their lowest and the maximum in winter when $\mathrm{pH}$ and DO were at their peak, presumably because oxygen and $\mathrm{pH}$ are key factors in the population dynamics of these parasites.

There was no relationship between parasite abundance and $\mathrm{CF}$ and the seasonal variation in CF was also not statistically significant $(p>0.05)$. Mhlanga (2000) and Kenmuir (1973) also found no significant seasonal variation in the condition of tigerfish in the lower Sanyati River basin, although they did not investigate parasitism. However, high CFs were recorded during the breeding season, possibly as a result of developed gonads. Further research is therefore recommended to investigate whether these parasites have an effect on the condition of the fish.
The monogeneans A. pikei, A. pseudonili and A. bracteatum were all found on the gills and it was not considered feasible to separate specimens into species considering the very high number of these parasites on the gills. Only A. bracteatum on the skin was considered for further analysis. The variance/mean ratio of $A$. bracteatum and Contracaecum larvae to the number of hosts was greater than 1, indicating that the parasites were aggregated. Consequently, most fish had few parasites, particularly the monogeneans, while few fish harboured a large number of parasites. Of note was that the A. bracteatum were more aggregated than the Contracaecum larvae as evidenced by the high variance/mean ratio. However, the variance/ mean ratio does not provide any information about the causes of aggregation because a number of different biological phenomena have been proposed to explain this flexible distribution (Poulin 2007).

According to Amarante et al. (2015), factors determining the degree of aggregation are not well understood. In the present study, it is assumed that the aggregative pattern could be a function of the life histories of the parasites. For example, in the case of the monogeneans which are hermaphrodites, it is assumed that they possibly aggregate after colonising their host. The aggregative distribution of monogeneans parasitising fish has also been observed by Tombi, Akoumba and Bilong Bilong (2014) in Oreochromis niloticus. Aggregation of the Contracaecum larvae could possibly be because of a single infection incident. Furthermore, $H$. vittatus is an intermediate host of the nematodes. Kennedy (1977) postulated that the aggregative distribution increases opportunities to meet a partner in order to reproduce.

The variance and mean ratio of $L$. hemprichii were approximately the same and therefore according to the approach by Elliott (1977), these parasites are not aggregated but randomly (or Poisson) distributed. Female Lamproglena, continuously release impregnated eggs into egg sacks, from which larvae hatch continuously, scatter and thereafter each complete an intricate free living life cycle before the impregnated parasite female becomes infective to another host (Madanire-Moyo \& Avenant-Oldewage 2013), hence the random infection pattern.

\section{Conclusion}

The slight seasonal variations in the occurrence of the parasites could probably be because of the thermal stability of the lake. Annulotrema bracteatum and Contracaecum larvae were aggregated on the fish host, whereas L. hemprichii exhibited a random distribution. Parasite diversity was the highest in winter and parasite abundance did not correlate with the season.

\section{Acknowledgements}

The authors would like to acknowledge the assistance rendered by the University of Zimbabwe Lake Kariba Research staff and also the provision of their laboratory facilities. 


\section{Competing interests}

The authors declare that they have no financial or personal relationships that may have inappropriately influenced them in writing this article.

\section{Authors' contributions}

All authors contributed equally to this work.

\section{Funding information}

Funding was received from the University of Johannesburg, a study bursary to N.M., running expenses from the University of Johannesburg (UJ) Faculty Research Committee and UJ Central Research committees to A.A.-O. This was supplemented by the National Research Foundation funding to A.A.-O.

\section{Data availability statement}

Data sharing is not applicable to this article as no new data were created or analysed in this study.

\section{Disclaimer}

The views and opinions expressed in this article are those of the authors and do not necessarily reflect the official policy or position of any affiliated agency of the authors.

\section{References}

Aaltonen, T.M., Jokinen, E. \& Valtonen, E.T., 1994, 'Antibody-synthesis in roach (Rutilus rutilus)-analysis of antibody-secreting cells in lymphoid organs with ELISPOTassay', Fish and Shellfish Immunology 4(2), 129-140.

Adams, A.M., Murrell, K.D. \& Cross, J.H., 1997, 'Parasites of fish and risks to public health', Review of Science and Technology 16(2), 652-660.

Al-Zubaidy, A.B., 2009, 'Prevalence and densities of Contracaecum sp. larvae in Liza abu (Heckel, 1843) from different Iraqi water bodies', Marine Science 20(1), 3-17.

Amarante, C.F., Tassinari, W., Luque, J.L. \& Pereira, M.J.S., 2015, 'Factors associated with parasite aggregation levels in fishes from Brazil', Revisita Brasileira Parasitologia Veterináira (24)2, 174-182.

Austin, A. \& Avenant-Oldewage, A., 2009, 'Ecological parameters of Lamproglena hoi (Copepoda: Lernaeidae) infection of the bushveld small scale yellowfish, Labeo barbus polylepis (Boulenger, 1907)', Onderstepoort Journal of Veterinary Research 76, 227-234.

Barson, M. \& Avenant-Oldewage, A., 2006, 'Nematode parasites of Clarias gariepinus (Burchell, 1822) from the Rietvlei Dam, South Africa', Onderstepoort Journal of Veterinary Research 73(2), 87-94.

Bashirullah, A.K. \& Hafizuddin, A.K.M., 2007, 'Seasonal distribution and population structure of $P$. fusiformis (Digenea: Bucephalidae) in $E$. vacha in Kaptai Lake, Bangladesh', Saber, Universidad de Oriente, Venezuela 19(2), 137-144.

Boomker, J., 1994, 'Parasites of South African freshwater fish. VI. 'Nematode parasites of some fish species in the Kruger National Park', Onderstepoort Journal of Veterinary Research 61(1), 35-43.

Branson, E.J. \& Southgate, E.J., 1992, 'Metazoan parasites', in R.L. Butcher (ed.) Manual of ornamental fish, pp. 68-73, British Small Animal Veterinary Association, London.

Buchmann, K. \& Uldal, A., 1997, 'Gyrodactylus derjavini infection in four salmonids: Comparative host susceptibility and site selection of parasites', Diseases of Aquatic Organisms 28(3), 201-209.

Buckle, C., 1996, Weather and climate in Africa, p. 312, Longman, Harlow.

Bush, A.O., Lafferty, K.D., Lotz, J.M. \& Shostak, A.W., 1997, 'Parasitology meets ecology on its own terms: Margolis et al. revisited', Journal of Parasitology 83(4), 575-583.

Christison, K.W., Van As, J.G. \& Basson, L., 1998, 'Annulotrema gill parasites of Okavango characins', Microscopy Society of Southern Africa Proceedings 28, 84.

Douëllou, L., 1992, A survey of fish parasites in Lake Kariba, Zimbabwe, University of Zimbabwe Lake Kariba Research Station Bulletin 1/92, University of Zimbabwe, Harare.
Douëllou, L. \& Erlwanger, K.H., 1993, 'Occurrence and distribution of two clinostomatic metacercariae in fishes from Lake Kariba, Zimbabwe', Transactions of the Zimbabwe Scientific Association 66, 35-40.

Douëllou, L. \& Erlwanger, K.H., 1994, 'Crustacean parasites of fishes in Lake Kariba, Zimbabwe, Preliminary Results', Hydrobiologia 287(3), 233-242.

Eissa, I.A.M., 2002, Parasitic fish diseases in Egypt, 1st edn., DarEl-Nahdda El-Arabia Publishing, Cairo, Egypt.

Elliott, J.M., 1977, Some methods for the statistical analysis of samples of benthic invertebrates, 2nd edn., Freshwater Biological Association, Ambleside.

Felis, K.J. \& Esch, G.W., 2004, 'Community structure and seasonal dynamics of the helminth parasite in Lepomis cyanellus and L. macrochirus from Charles' pond North Carolina: Host size and species as determinants of community structure', Journal of Parasitology 90(1), 41-49.

Garnick, E. \& Margolis, L., 1990, 'Influence of four species of helminth parasites on orientation of seaward migrating sockeye salmon (Onchorhynchus nerka) smolts', Canadian Journal of Fisheries and Aquatic Sciences 47(12), 2380-2389.

Guégan, J.F., Lambert, T.A. \& Birgi, É., 1988, 'Some observations on the branchial parasitism from characid fishes, genus Hydrocynus in West Africa. Description of a new species, Annulotrema pikoides n. sp. (Monogenea, Ancyrocephalidae) from Hydrocynus vittatus (Castelnau, 1861)', Annales de Parasitologie Humaine et Comparée 63(2), 91-98.

Hanzelova, V. \& Zitňan, R., 1985, 'Epizootiologic importance of the concurrent monogenean invasion in carp', Journal of Helminthology 22(4) 277-283.

Huizinga, H.W., 1967, 'The life cycle of Contracaecum multipapillatum (Von Drasche, 1882) Lucker, 1941 (Nematoda: Heterocheilidae)', Journal of Parasitology 53(2), 368-375.

Junker, K., Boomker, J. \& Booyse, D.G., 1998, 'Pentastomid infections in Cichlid fishes in the Kruger National Park and the description of the infective larva of Subtriquetra rileyi $\mathrm{n} . \mathrm{sp}^{\prime}$, Onderstepoort Journal of Veterinary Research 65(3), 159-167.

Kenmuir, D.H.S., 1973, 'The ecology of the tigerfish, Hydrocynus vittatus Castelnau, 1861 in Lake Kariba', Occasional Papers of the National Museums and Monuments of Rhodesia 3(B5), 115-170.

Kennedy, C.R., 1997, 'Long term and seasonal changes in composition and richness of intestinal helminth communities in eels Anguilla anguilla of an isolated English river', Folia Parasitologica 44(4), 267-273.

Kičinjaová, M.L., Barson, M., Gelnar, M. \& Řehulkov, E., 2017 'Two new species of Annulotrema (Monogenea: Dactylogyridae) from Hydrocynus vittatus (Characiformes: Alestidae) in Lake Kariba, Zimbabwe', Journal of Helminthology 92(4), 467-476.

Koskivaara, M., Valtonen, E.T. \& Prost, M., 1991, 'Dactylogyrids on the gills of roach in central Finland: Features of infection and species composition', Internationa Journal of Parasitology 21(5), 565-572.

Kuchta, R, Burianova, A, Jirku, M, deChambrier, A, Oros, M, Brabec, J, et al., 2012 'Bothriocephalidean tapeworms (Cestoda) of freshwater fish in Africa, including erection of Kirstenella n. gen. and description of Tetracampos martinae n. $\mathrm{sp}^{\prime}$ Zootaxa 3309(1), 1-35.

Kunutu, K.D., Tavakol, S, Halajian, A., Baker, C, Paoletti, M., Heckmann, R.A et al, 2018, 'Expanded description of Lamproglena cleopatra Humes, 1957 (Lernaeidae: Copepoda) from Labeo spp. with a key to species of Lamproglena von Nordmann, 1832', Systematic Parasitology 95(1), 91-103.

Lafferty, K.D. \& Kuris, A.M., 1999, 'How environmental stress affects the impacts of parasites', Limnology and Oceanography 44(3), 925-931.

Luus-Powel, W.J., Jooste, A. \& Junker, K., 2008, 'Pentastomid parasites in fish in the Olifants and Incomati river systems, South Africa', Onderstepoort Journal of Veterinary Research 75(4), 323-329. https://doi.org/10.4102/ojvr.v75i4.108

Mabika, N., Barson, M., Van Dyk, C. \& Avenant-Oldewage, A., 2016, 'Taxonomy, distribution and prevalence of parasites of tigerfish, Hydrocynus vittatus (Castlenau, 1861) in the Sanyati basin, Lake Kariba, Zimbabwe', Acta Parasitologica 61(3), 614-620.

Madanire-Moyo, G.G. \& Avenant-oldewage, A., 2013, 'On the development of a parasitic copepod, Lamproglena clariae Fryer, 1956 (Copepoda, Lernaeidae) infesting on the sharptooth catfish, Clarias gariepinus', Crustaceana 86(4), 416-436.

Madanire-Moyo, G. \& Barson, M., 2010, 'Diversity of metazoan parasites of the African catfish Clarias gariepinus (Burchell, 1822) as indicators of pollution in a subtropical river system', Journal of Helminthology 84(2), 216-227.

Marcogliese, D.J., 2005, 'Parasites of the superorganism: Are they indicators of ecosystem health?', International Journal of Parasitology 35(7), 705-716.

McHugh, K.J., Smit, N.J., Van Vuren, J.H.J., Van Dyk, J.C., Bervoets, L., Covac, A. et al., 2011, 'A histology-based health assessment of the tigerfish, Hydrocynus vittatus from a DDT affected area', Physics and Chemistry of the Earth 36(14), 895-904.

Mhlanga, W., 2000, 'An assessment of the fish population of the lower reaches of the Sanyati River, Zimbabwe', African Journal of Aquatic Science 25(1), 84-88.

Mo, T.A., 1997, 'Seasonal occurrence of Gyrodactylus derjavini (Monogenea) on brown trout, Salmo trutta, and Atlantic salmon, S. salar, in the Sandvikselva River, Norway', Journal of Parasitology 83(6), 1025-1029. https://doi.org/10.2307/3284356

Möller, H. \& Anders, K., 1986, Diseases and Parasites of Marine Fishes, Moller publications, Kiel, Möller, pp. 365.

Paperna, I., 1973, 'New species of Monogenea (Vermes) from African freshwater fish. A preliminary report', Revue de Zoologie et de Botanique Africaines 87(3), 505-518. 
Paperna, I., 1979, 'Monogenea of inland water fish in Africa. Musee Royal de l'Afrique Centrale, Tervuren Belgique, Annales, Ser. IN-8', Science Zoologiques 8(226), 1-127.

Pardeshi, P.R., Hiware, C.J. \& Wangswad, C., 2012, 'Histopathology of the liver of Mastacembelus armatus (Lacepede, 1800) due to trematode parasite, Allocreadium khami n.sp', Journal of Parasitic Diseases 36(1), 53-55.

Pauly, D., 1983, Some simple methods for the assessment of tropical fish stocks, FAO Fisheries Technical Paper, 234, p. 52, Food and Agriculture Organisation, United Nations, Rome.

Poulin, R., 2007, 'Are there general laws in parasite ecology'? Parasitology 134(Pt 6), 763-776. https://doi.org/10.1017/S0031182006002150

Price, C.E., Peebles, H.E. \& Bamford, T., 1969, 'The monogenean parasites of African fishes: IV. Two new species from South African hosts', Revue de Zoologie et de Botanique Africaines 79(1), 117-124.

Puinyabati, H., Singha, R., Shomorendra, M. \& Kar, D., 2010 'Seasonal occurrence of helminth parasites infecting Anabas testudineus in Awangsoi lake, Manipur. Assam', University Journal of Science and Technology 6, 42-45.

Ravichandran, S., Balasubramanin, T. \& Kannupandi, T., 2007, 'Incidence of parasitic isopods on the fish Sphyraenaobtusata', Research Journal of Parasitology 2(1), $45-50$.

Reed, C.C., Basson, L. \& Van As, L.L., 2002, 'Myxobolus species (Myxozoa), parasites of fishes in the Okavango River and Delta, Botswana, including descriptions of two new species', Folia Parasitologica 49(2), 81-88.
Skelton, P., 2001, A complete guide of freshwater fishes of Southern Africa, Struik Publishers, Cape Town.

Šimková, A., Jarkovsky, J., Koubková, B., Barus, V. \& Prokes, M., 2005, 'Associations between fish reproductive cycle and the dynamics of metazoan parasite infections', Parasitology Research 95(1), 65-72. https://doi.org/10.1007/ s00436-004-1261-y

Tavares-Dias, M., Oliveira, M.S.B., Gonçalves, R.A. \& Silva, L.M.A., 2014, 'Ecology and seasonal variation of parasites in wild Aequidens tetramerus, a Cichlidae from the Amazon', Acta Parasitologica 59(1), 158-164.

Tombi, J., Akoumba, J.F. \& Bilong Bilong, C.F., 2014, 'The monogenean community on the gills of Oreochromis niloticus from Melen fish station in Yaounde, Cameroon', International Journal of Modern Biological Research 2(2), 16-23.

Tsotetsi, A.M., Avenant-Oldewage, A. \& Mashego, S.N., 2004, 'Aspects of the ecology of Lamproglena clariae (Copepoda: Lernaeidae) from the Vaal river system, South Africa', Journal of Crustacean Biology 24(4), 529-536.

Whitfield, A.K. \& Heeg., J., 1977, 'On the life cycles of the cestode Ptychobothrium belones and nematodes of the genus Contracaecum from Lake St. Lucia, Zululand', South African Journal of Science 73(4), 121-122.

Xenopoulos, M.A., Lodge, D.M. \& Alcamow, J., 2005, 'Scenarios of freshwater fish extinctions from climate change and water withdrawal', Global Change Biology 11(10), 1557-1564. 